\title{
PREVALENCE OF SARCOCYSTIS SPP. IN SHEEP AND GOATS AND ITS EFFECT ON SOME BLOOD CONSTITUENTS IN SHARKIA PROVINCE
}

\author{
Nasr, S. S. M., Hussen, E. M. * and Soad Mekawy ${ }^{* *}$ \\ Parasitology, Biochemistry ${ }^{*}$ and clinical pathology ${ }^{* *}$ departments \\ Animal Health Research Institute (Zagazig branch)
}

\begin{abstract}
This study was carried out on slaughtered sheep and goats in different slaughter houses in Sharkia Province to determine the prevalence of ovine and caprine Sarcocystis infection and effect on some biochemical clinical pathological parameters.

Parasitological examination of faecal samples revealed presence of eggs of internal parasites in 25(41.67\%) lambs(less 9 month) \{12(48\%) nematodes, $7(28 \%)$ trematode $) \& 6(24 \%)$ mixed infection\} $29(48.33 \%)$ adult (more 2 year) ( sheep $\{15(51.72 \%)$ nematodes, 10 (34.48\%) trematode \& 4(13.79\%) mixed infection\}, 19 (47.50\%) young goats $\{11(57.89 \%)$ nematodes, 5(26.32\%) trematode \& 3(15.79\%) mixed infection\}, 24 (60\%) adult goats\{14(58.33\%) nematodes, $5(20.83 \%)$ trematode \&5 (20.83\%) mixed infection\}.
\end{abstract}

Serologically, antibodies against Sporocystis spp. infection were observed in sheep serum samples were $47.50 \%$ (57) \& 40\% (32) for goats serum samples. The infection in adult animals were $\{34$ (56.67\%) in sheep and 19 (47.50\%) in goats $\}$ more than in young animals 23 (38.33\%) in sheep and13 (32.50\% in goats\}. Sarcocystis in sheep distributed as macrocystis $116.67 \%$ for young and $11.67 \%$ adult), microcystis ovi-cans (10\% young, 5\% adult) and mixed infection (macrocystis and microcystis) were (56.67\% young, $38.33 \%$ 
adult), meanwhile in goats Sarcocystis macrocystis (25\% young and $15 \%$ adult), microcystis (capricans) (15\% young, $12.5 \%$ adult) and mixed infection (macrocystis and microcystis) $47.50 \%$ for young, $32.50 \%$ for adult).

Sarcocystis infection in Sheep and goats induced a significant decrease in leukocytic count, monocytes, total protein, albumin, globulin, lymphocytosis, neutrophilia, non significant effect in basophils and eosinophilis beside significant rise AST,ALT\& ALP.

It could be concluded that the Sarcocystis spp infected both sheep and goat, the infection in adult were more than in young ones. Sarcocystis induces changes in biochemical parameters. Therefore, it has of great importance the human to be trained not to feed their dogs and cats with uncooked meat, and abattoir remnants were burned to be effectively broken of infection cycle between the intermediate and the definitive hosts.

\section{INTRODUCTION}

Sarcocystis is one of the most prevalent parasites in livestock (Metwally, et al 2013). Sarcocystis spp. normally develops in 2-host cycles consisting of an intermediate host and the final host; each host may be infected with more than one Sarcocystis spp. (Bhatia 2000). It is one of the most prevalent protozoan parasites in striated muscles of animals as sheep and goat (Abo Shepard 1996). Sarcocystis infections of sheep and goats are common throughout the world (Melinda et al, 2010). Sarcocystis have 4 species were identified from sheep (Britt and Baker 1990). Of these, S.ovicanis (synonymous=S.tenella) and S. arieticanis, pathogenic spp form microscopic cysts and are transmitted via Canids, 
the definitive hosts, whereas S.ovifelis (synonymous $=S$ gigantea) and $\mathrm{S}$. medusiformis, non-pathogenic species, form macroscopic cysts and are transmitted via felids (Aysen etal 2007). Sarcocystis considered of economic importance, because ruminants will act as an intermediate host for a wide range of species (Dubey etal.1988). Control of Sarcocystis relied on preventing conta-mination of pasture and water with feces of dogs, foxes and cats (Buxton 1998).

The main objective of the study was to address the prevalence of natural infection of sheep and goats in Sharkia province with Sarcocystis and its effect on some blood parameters.

\section{MATERIAL AND METHODS}

\section{Animal:}

A total number of 200 animals (sheep and goats of both sexes and young animals less than 9 month and adult animals more than 2 year), 120 sheep (60 young and 60 adult ones) and 80 goats (40 young and 40 adult ones) were surveyed for the presence of Sarcocystis during 2012 from different slaughtered houses in Sharkia province (Zigzag, Abu Hamad, Hehia AND durp Nigm centers).

\section{Blood samples:}

Before animal slaudhtering 2 blood and 1 Faecal samples were taken from each animal, $1^{\text {st }}$ blood sample was taken in tube contains EDTA for total and differential leukocytic count, $2^{\text {nd }}$ sample was used for obtain a clear serum for estimation of some biochemical parameters and diagnosis of Sarcocystis infections by (ELISA). 
Faecal samples:

Before animal slaughtering faecal sample was taken from each one for parasitological examination.

\section{Muscle samples collection:}

Post animal slaughtering, tissue samples were taken from oesophagus; heart and diaphragm muscles, preserved in ice bags and trans-ported from the slaughter house to the Laboratory for detection of Sarcocystis by:

1- Macroscopic examination: Fresh muscle samples were examined macrosco-pically for presence of macroscopic Sarcocystis cysts (Huong 1999) and,

2- Microscopic examination: For detection of microscopic Sarcocystis cysts:-

A) Small pieces of fresh muscle were compressed between two slides and examined microscopically (Mowafy, 1993).

B) Digestion method, $100 \mathrm{~mL}$ of digestion medium $(2.5 \mathrm{~g}$ pepsin 700 and $10 \mathrm{~mL} \mathrm{HCL}$ in $1 \mathrm{~L}$ phosphate-buffered saline) was added to $50 \mathrm{~g}$ (homogenized)and placed in a shaking water bath at $37^{\circ} \mathrm{C}$ for 30 min. The suspension was then centrifuged for $10 \mathrm{~min}$ at $1500 \mathrm{rpm}$ and a precipitate smear was prepared, fixed with absolute methanol stained with Giemsa and examined by light microscopy at x400 and x1000 (Dubey et al. 1989). 
Serological diagnosis of Sarcocystis (ELISA) Serum samples from all animals were subjected to ELISA for detection of antibody to Sarcocystis (Voller, et al. 1980) Antigen was prepared according to Morsy, etal (1994)

\section{Determination of leukogram and some biochemical parameters:}

Post diagnosis of Sarcocystis infection by macroscopic,microscopic and ELISA beside parasitological examinations of faecal samples, 20 blood samples (adult animals that free from internal and external parasites (10 sheep and 10 goats) were divided into 2 group, 10 animal in each (5 sheep and 5 goats) $1^{\text {st }}$ group blood samples from healthy sheep and goats free from internal and external parasites and Sarcocystis (control), $2^{\text {nd }}$ group blood samples from sheep and goats free from internal and external parasites infected with microscopic Sarcocystis and +ve ELISA. Total and differential leukocytic count was estimated by using the improved Neubauer chamber and Natt and Herrick,s solution as diluting fluid according to (Jain, 1993), serum samples were used for determination of total protein calorimetrically (Doumas etal 1981), albumin (Drupt 1974) and globulin was calculated as difference between total protein and albumin. (AST \&ALT) (Reitman and Frankel (1957)), ALP (John, 1982).

\section{Statistical analysis:}

The obtained data were statistically Petrie and Watson (1999). 


\section{RESULT AND DISCUSSION}

In the present study, serologically Sarcocystis sp. prevalence by ELISA was in ovine $47.50 \%$ more than in caprine $40 \%$ (table, 2). Same prevalence were reported by Mahran (2009) found that the prevalence of ovine Sarcocystis was $41.26 \%$ and $36.92 \%$ in caprine in Red Sea Province. Higher infection rates have also been recorded in Aswan province were $88 \%$ (Bashtar, et al.1990). Same prevalences rates have also been recorded in other countries that have similar climatic conditions, such as ovine Sarcocystis spp. in Turkey were 49\% (Sevinç, 2000), $55 \%$ in South Australia (Ford 1987) 38\% in goats in Libya (Fathi and Abel Haseeb 2006). This difference in prevalence of Sarcocystis infection may be due to different populations of stray dogs which play an important role in infection with Sarcocystis. (AboShehada, 1996).

The prevalences of infection with Sarcocystis spp in young animals were $38.33 \%$ for sheep, $32.50 \%$ for goat less than adult age $56.67 \%$ for sheep and $32.50 \%$ for goat (table 2). Same observation was recorded by Martinez, et.al. (1989) and Abo-Shehada (1996) stated that prevalence of ovine sarcocystosis was higher in adult sheep than young ones. Prevalence of Sarcocystis infection in Czechoslovakia in young sheep were $35.67 \%$ and $61 \%$ in adult sheep Svobodova and Nevole (1990), $22.6 \%$ in meat-producing animals under 6 months of age in Iraq (Latif et al. 1999). Sarcocystis spp. infection was higher in old camels (>5 year rather than young camels (<2 year) Lotfi, et. al. (1995). 
Gross and microscopical examination of muscle samples of 120 sheep and 80 goats slaughtered in Sharkia Province abattoir revealed that the infection rate of Sarcocystis was $47.50 \%$ in sheep distributed as (macrocystis $16.67 \%$ for young $\& 11.67 \%$ adult-microcystis (ovicans) $10 \%$ young $5 \%$ mature-mixed infection (macrocystis and microcystis were $56.67 \%$ for young, $38.33 \%$ for adult one) (table 3), meanwhile in goats Sarcocystis was $40 \%$ in sheep distributed as (macro-cystis $25 \%$ for young and $15 \%$ adult - microcystis (capricans) $15 \%$ young, $12.5 \%$ adult - mixed infection (macrocystis and microcystis were $47.50 \%$ for young, $32.50 \%$ for adult one) (table, 3). Same results were recorded by $\boldsymbol{A l}$ Sultan, et.al. (2012) who found microcystis ovicans in heart muscles of slaughtered sheep in Kelantan (Malaysia). Al-Taee, et al. (2009) recorded microcystis ovicans and microcystis capricanis in heart muscles of slaughtered sheep and goats in Iraq.

The present study showed that a significant decrease in total leukocytic count and monocyte associated with significant increase in neutrophils and lymphocyte beside isignignificant effect in eosinophilis and basophilis in sheep and goats infected with Sarcocystis spp (table 4). These changes in leukocytic count may be due to infections which stimulate migration of leukocytes from peripheral blood toward the tissue where parasites was found or to the regional lymphoid tissues, and hence total leukocyte decreased below the normal level (Okur, etal.1995). Decreased monocytes may be due to monocytes that were drawn from the blood toward the infected tissue and transformed into macrophages to attack the parasites which found mainly in tissues (Melinda et.al 2010). Increased lymphocytes are responsible for mediating immunity against parasites (Abdel-Azeem, etal. 2009). 
Our study revealed a significant reduction in total protein, albumin, globulin beside significant increase in AST, ALT and ALP in sheep and goats infected with Sarcocystis spp (table, 5). Similar results were recorded by Nabih and Abd El- Hamid (1984) and Fayer and Lunde (1987). This result may be due to the degenerative and necrotic changes accompanied the damage of muscles due to Sarcocystis spp infection and its toxins (Keneko, 1989). More explanations were presented by (Gharib, 1989) who reported that this enzyme is widely distrbuted allover muscle cells and tissues. Furthermore, its increase reflects an active pathological process in muscles due to Sarcocystis spp. Sarcocystis spp induce significant decrease in $\mathrm{T}$ protein, albumin and globulin in calves (Dessouky, et al. (1984). Reduction in protein picture in animals infected with Sarcocystis spp may be due to decrease in gamma globulin (Gill, etal 1988). Sarcocystosis in calves induced elevation in liver enzymes (Nevole, et al. 1986). Elevation in liver enzymes may be due to development muscular cysts lead to degenerative changes, rupture of muscle fibers and sometimes myositis develops in which led to increase liver enzymes (Nevole et al 1981). Sarcocystsis cause degenerative hepatitis lead to increase liver enzymes (Prasse and Fayer 1981).

It could be concluded that the sporocystis spp in both sheep and goat, infection in adult animals were more than young one. Sarcocystis infections induce changes in biochemical parameters. Therefore, it has of great importance that human not feed their dogs and cats with uncooked meat, and the abattoir remnants to be burned, in order to be effectively broken of infection cycle between the intermediate and the definitive hosts. 
Prevalence of sarcocystis spp. In sheep and goats and its ...

Table (1): Seroprevalence of sarcocystis spp. infection in sheep and goats sera by ELISA

\begin{tabular}{|c|c|c|c|c|c|c|c|c|}
\hline \multirow{3}{*}{ age } & \multirow{3}{*}{$\begin{array}{l}\text { Mean } \\
\text { of -ve } \\
\text { control }\end{array}$} & \multirow{3}{*}{$\begin{array}{l}\text { Cut of } \\
\text { value }\end{array}$} & \multicolumn{3}{|c|}{ sheep } & \multicolumn{3}{|c|}{ goats } \\
\hline & & & \multirow{2}{*}{$\begin{array}{l}\text { T. examined } \\
\text { sample }\end{array}$} & \multicolumn{2}{|c|}{ +ve sample } & \multirow{2}{*}{$\begin{array}{c}\text { T. examined } \\
\text { sample }\end{array}$} & \multicolumn{2}{|c|}{ +ve sample } \\
\hline & & & & No. & $\%$ & & No. & $\%$ \\
\hline young & 0.146 & 0.292 & 60 & 23 & 38.33 & 40 & 13 & 32.50 \\
\hline adult & 0.146 & 0.292 & 60 & 34 & 56.67 & 40 & 19 & 47.50 \\
\hline total & 0.146 & 0.292 & 120 & 57 & 47.50 & 80 & 32 & 40 \\
\hline
\end{tabular}

Table (2): macro and micro sarcocystis cysts spp. infection in sheep and goats

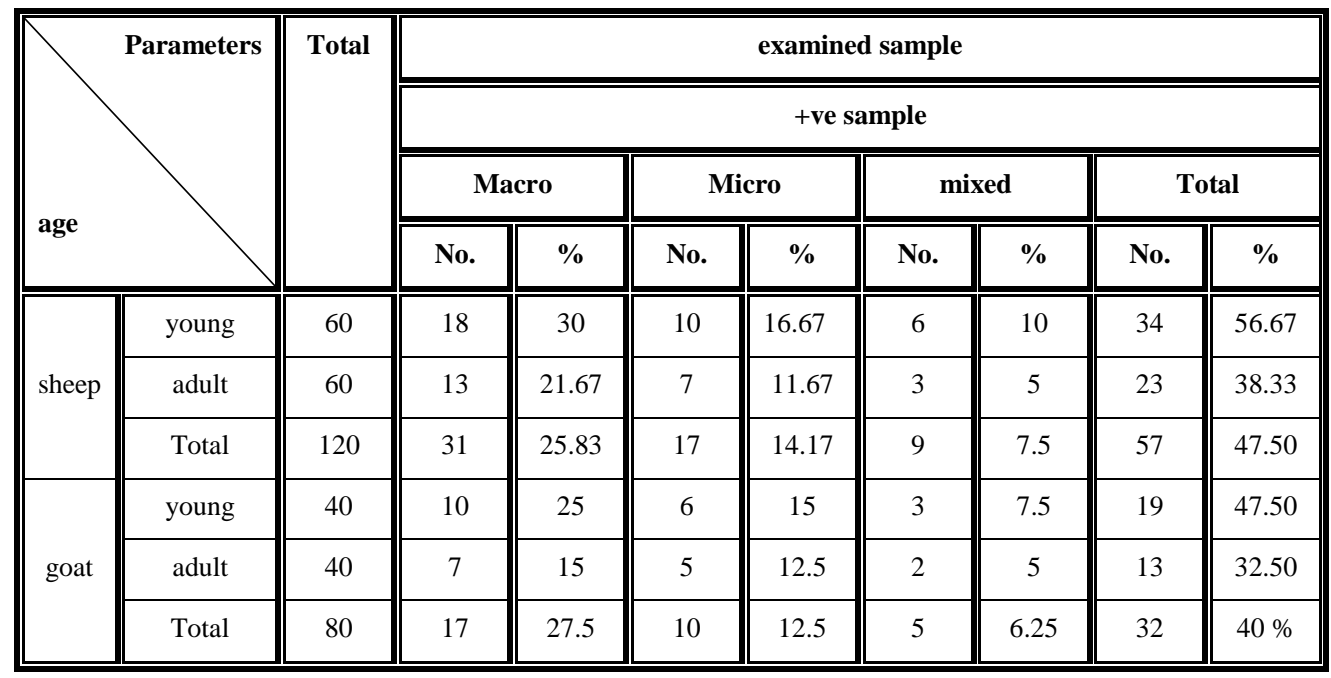

Table (3): Leukogram of healthy and diseased sheep and goats $(n=5)$

\begin{tabular}{|c|c|c|c|c|c|c|c|}
\hline \multirow{2}{*}{\multicolumn{2}{|c|}{ Group }} & \multirow{2}{*}{$\begin{array}{c}\text { TLC } \\
\mathbf{x} 10^{3} / \mathbf{u l}\end{array}$} & \multicolumn{5}{|c|}{ differential leukocytic count (x10 $3 / u l)$} \\
\hline & & & Neutrophils & Lymphocytes & Eosinophils & Basophilis & Monocytes \\
\hline \multirow[t]{2}{*}{ sheep } & control & $8.33 \pm 0.14$ & $2.98 \pm 0.04$ & $3.62 \pm 0.03$ & $0.50 \pm 0.03$ & $0.58 \pm 0.11$ & $0.65 \pm 0.16$ \\
\hline & Diseased & $7.91 \pm 0.10 *$ & $3.10 \pm 0.03 *$ & $3.73 \pm 0.04 *$ & $0.51 \pm 0.02$ & $0.33 \pm 0.08$ & $0.24 \pm 0.06^{*}$ \\
\hline \multirow[t]{2}{*}{ goats } & control & $8.19 \pm 0.11$ & $3.30 \pm 0.05$ & $3.58 \pm 0.03$ & $0.49 \pm 0.09$ & $0.24 \pm 0.08$ & $0.58 \pm 0.14$ \\
\hline & Diseased & $7.67 \pm 0.18 *$ & $3.44 \pm 0.04 *$ & $3.36 \pm 0.08 *$ & $0.50 \pm 0.08$ & $0.17 \pm 0.04$ & $0.20 \pm 0.09 *$ \\
\hline
\end{tabular}

$* \mathrm{P}<0.05$

Kafrelsheikh Vet. Med. J. Vol. 11 No. 2 (2013) 
Nasr, S. S. M. et., al.

Table (4): Serum protein picture and liver enzymes of healthy and diseased sheep and goats $(n=5)$

\begin{tabular}{|c|c|c|c|c|c|c|c|c|}
\hline \multirow[b]{2}{*}{ Group } & \multirow[t]{2}{*}{ arameters } & \multicolumn{4}{|c|}{ protein picture (g/dl) } & \multicolumn{3}{|c|}{ liver enzymes $(\mu / L)$} \\
\hline & & T.protein & Albumin & Globulin & A/Gratio & AST & ALT & ALP \\
\hline \multirow[t]{2}{*}{ sheep } & control & $7.36 \pm 0.26$ & $3.93 \pm 0.22$ & $3.43 \pm 0.10$ & $1.15 \pm 0.22$ & $54.86 \pm 1.43$ & $39.43 \pm 1.51$ & $58.09 \pm 1.74$ \\
\hline & Diseased & $6.48 \pm 0.19 *$ & $3.47 \pm 0.20 *$ & $3.01 \pm 0.14 *$ & $1.15 \pm 0.18$ & $61.54 \pm 1.81 *$ & $44.52 \pm 1.33 *$ & $66.38 \pm 1.94 *$ \\
\hline \multirow[t]{2}{*}{ goats } & control & $6.93 \pm 0.41$ & $3.81 \pm 0.19$ & $3.12 \pm 0.17$ & $1.22 \pm 0.25$ & $48.84 \pm 1.40$ & $43.17 \pm 1.42$ & $49.81 \pm 1.53$ \\
\hline & Diseased & $5.61 \pm 0.40 *$ & $3.04 \pm 0.22$ & $2.57 \pm 0.16^{*}$ & $1.18 \pm 0.30$ & $55.07 \pm 1.63 *$ & $48.72 \pm 1.63 *$ & $57.17 \pm 2.32 *$ \\
\hline
\end{tabular}

$* \mathrm{P}<0.05$

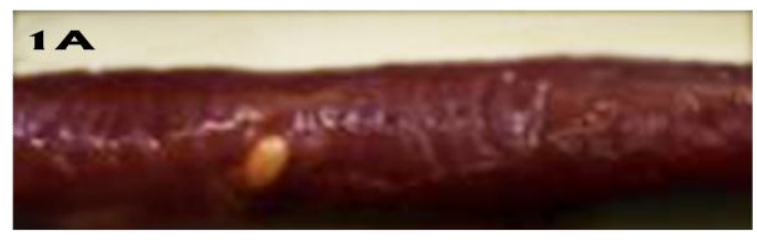

$1 \mathbf{B}$

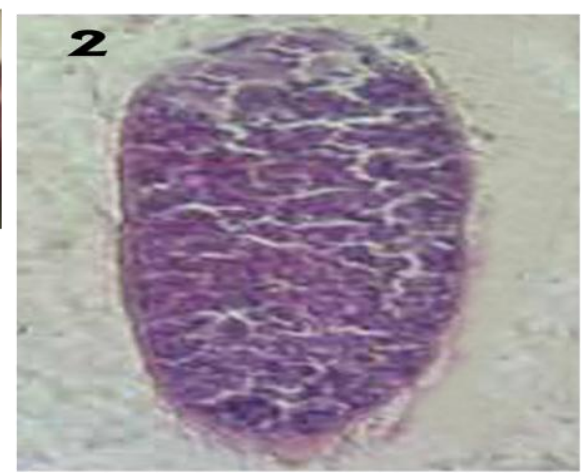

Fig. (2) sarcocystis ovicanis

Fig. (1)
A) Macrocystis in oesephagus of goat thick type.
B) Macrocystis in oesephaous of goat thin type.

\section{ACKNOWLEDGMENT}

The authors thank Dr Waheed Moussa prof of Parasitology and head of biotechnology Lab., faculty of Vet Med Cairo Uni. for serodiagnosis of Sarcocystic spp. Antibodies by ELISA technique 


\section{REFERENCES}

- Abdel-Azeem, A; Gamal, A ;Thabet, $S$ and El-Mahy E. (2009): Lambs infected with uvnattenuated Sporocysts of sarcocystis ovicanis produced abnormal sarcoc- yst and induced protective immunity against a challenge infection. Korean J Paras. 47 (2)131-138,

- Abo-Shehada M. (1996): Age variations in prevalence of sarcocystosis in sheep and goats from northern and central Jordan. Prev Vet Med $27,135-140$

- Al-Sultan, S. Norlida O, Zarina M and Abo Rahman, G (2012): Histopathogical Appraisal of Ovine Sarcocyst in Kelantan. J. of Adv Bioc \& Patho Res. 2(4) 13-17

- Al-Taee, A; Al-Hyali, N and Al-Badree, M (2009): Seroprevalence of antibodies-against Sarcocystis gigantea in different hosts in Iraq. Iraq Vet. Med. J. 23(1)10-14

- Aysen B., Öznur Y. and Zafer K. (2007): the prevalence of ovine Sarcocystis species in Izmir province. Ankara Üniv Vet Fak Derg, 54, 11-16,

- Bhatia B (2000): Textbook of vet protozoology, $1^{\text {st }}$ Ed. ICAR, New Delhi.

- Bashtar A, El-Assal F and Sakran T.(1990): Merogony and cyst formation of Sarcocystis ovicanis infecting sheep in correlation to pathogenicity. Bull Fac Sci Cairo Univ. 58: 17-31.

- Britt D. and Baker J. (1990): Causes of death and illness in the native sheep of North Ronaldsay, Orkney. I. Adult sheep. Brit Vet J, 146, 129-142. 
- Buxton D (1998): Protozoan infection (Toxoplasma gondii and Sarcocystis spp.) in sheep and goats: recent advances. Vet Res; 29:89-99.

- Dessouky, I.; Mohamed, A.; Nassar, A and Hilali, M. (1984): Haematobiochem-ical changes in buffalo calves inoculated with Sarcocystis fusiformis from cats. Vet. Parasitology,14(1), 1-6

- Doumas, B.; Certor, R; Peers, $T$ and Schafler, $R$ (1981): A candidat reference method for estimation of total protein in serum. Clin. Chem. (27) $1642-1647$

- Drupt, F. (1974): Colorimetric determination of albumin .Phar Bio. (9)777-779

- Dubey, J.; Fayer, R. and Speer, C. (1988): Experimental Sarcocystis hominis infection in cattle lesions and ultrastrucure of sarcocysts. J Parasit. 47: 75-79.

- Dubey J., Speer C. and Fayer R (1989): Sarcocystosis of animals and man, $1^{\text {st }}$ Ed. CRC Press Inc., Boca Raton

- Fathi, M. and Abdel Haseeb, S. (2006): Incidence and hazardous effect of some parasitic infestation of sheep and goats slaughtered at Al-Niqat Al Kams Province. 12 Sci. Cong. Fac. Vet. Med. Assiut Univ. Egypt. 199- 215.

- Fayer, R. and Lunde M. (1987): Changes in serum proteins and in $\mathrm{IgG}$ and $\operatorname{IgM}$ in calves experimentally infected with sarcocystis from dogs. Vet Parasi; 26:13-20 
- Ford, G. (1987): Hosts of two canid genera, the red fox and the dog as alternat vector in transmission of Sarcocysts from sheep. Vet Para.26:13-20

- Gharib, H.(1989): studies of enzymatic changes in blood of newly born calves and their relation to some common diseases. MVSc Thesis, Fac. Vet. Med. Cairo Univ.

- Gill, H.; Charleston, A. and Moriarty, M (1988): Immunosuppression in Sarcocystis muris-infected mice: evidence for suppression of antibody and cell-mediated responses to a heterologous antigen. Imm Cell Biol. $66(3): 29$

- Harlow, E. and lane, D. (1988): Antibodies a laboratory manual in immunassy cold spraying Harber laboratory pub. New York: 553: 121-127.

- Jain, $N$ (1993): Essentials of Vet Hematology.Lca and Febigor, Philadelphia.

- John, D (1982): Mouthed for estimation of Alkaline Phosphates. $9^{\text {th }}$ Ed 80

- Keneko, J. (1989): Clinical Biochemistry of Domestic Animal. Academic Press Inc., New York, London

- Khulbe, D.; Kushwah, A. and Kushwah, H. (1989): Biochemistry of the various fractions of sarcocystis fusiformis of buffaloes.Vet. Parasit. 31:1-5.

- Latif, B; Al-Delemi, J; Mohammed, B and Al-Amiry, A (1999): Prevalence of Sarcocystis spp. in meat-producing animal in Iraq. Vet Paras, 84, 85-90 
- Lotfi; A.; El-Khateib, T.; Fathi, S. and Said, M. (1995): Incidence of hydatid cysts in camels in Upper Egypt. Assiut Vet. Med. J. 31 (61) $35-41$

- Mahran, O. M.(2009): Sarcocystis infection in sheep and goats slaughtered in Shalatin Abattoir, Red Sea Governorate. Assiut Vet Med J,55(121) 41-55

- Martinz, A.; Moreno, T.; Martinz, F. and Martinz, S. (1989): Prevalence of ovine sarcocystosis in Cordoba, Spain. Rev Iber Parasitol, 49, 283-285.

- Melinda, G; Gabor, R; Mukesh S. and Mark, R (2010): chronic myositis in an Australian alpaca associated with Sarcocystis spp. J Vet Diagn Invest 22:66-69

- Metwally, Asmaa M, Mahmoud R; Amira A and Mosaab A (2013): Microscop- ical and serological studies on Sarcocystis infection with first report of S. cruzi in buffaloes in Assiut, Egypt. J Parasit Dis. 93(4) 27-37.

- Morsy, T.; Abdelmawla, M.; Salama, M.; Hamdi, N. (1994): Assessment of intact Sarcocystis cytozoites as an ELISA antigen. J. Egypt Soc Parasit 24, 85-91

- Nabih, I. and Abd El-Hamid, A. (1984): Biochemical studies on buffaloes bulls infected with Sarcocystis spp. vet. Parasit., 27:137-146

- Nevole M Malota L and B Koudela, B (1986): Catalytic activity of selected serum enzymes in sarcocystosis in calves. Acta Vet. Brno, 55: $81-84$ 
- Okur. H.; Kandemir, O. and Şahin. I. (1995): investigation on sarcocystis species in the cattle and the sheep in Bayburt. T Parazitol Derg, 19, 113-118.

- Petrie, A. and Watson, P. (1999): Statistics for Veterinary and Animal Science 1st Ed. 90-99, the Blackwell Science LTd, United Kingdom.

- Prasse, K. and Fayer, R.(1981): Hemato-biochemical of Experimental Acute Sarcocystis bovicanis Infection in Calves. Vet. Pathol, 18, 358-367.

- Reitman, S. and Frankel, S. (1957): Colorimetric method for determination of serum AST and ALT Am.J.Clin. Path, 28:56.

- Savini, G.; Robertson, I. and Dunsmore, J. (1997): Class specific antibody response in cattle following experimental challenge with sperocystis or merozoites of sarcocystis crusi.Vet.Parasitolog, 72:121127.

- Sevinç, F.; Altınöz, F. and Aldemir, O. (2000): Koyunlarda sarcocystis türlerinin yaygınlığı. Vet Bil Derg, 16, 75-79.

- Svobodova, V. and Nevole, M. (1990): Use of muscle digestion method and indirect immunofluorescence reaction in the diagnosis of sarcocystosis in sheep. Acta Vet Brno, 59, 157-170.

- Voller, A.; Bidwell, D.; Barlett, A. (1980): Enzyme linked immunosorbent assay. In: Manual of Clinical Immunology. (Rose, N.; Friedman, H. Ed). Washington D.C. (Am. Soc. Microbiol.). pp. 359371. 
معدل الإصابة بالسركوسيست في الأغنام و الماعز وتأثثر ها على بعض مكونات الدم بمحافظة الثرقية

د./ سامي شوقي محمد السيد نصر د./ إيهاب محمد حسين" د./ سعاد مكاوي" " .

\section{أقسام الطفيليات الكيمياء" الباثولوجيا الإكلينيكية" "}

معهد بحوث صحة الحيوان (فرع الزقازيق)

طفيل الساركوسيستس من الأوليات الطفيلية والتي تسبب خسائر اقتصادية كبيرة في الأغنام والماعز

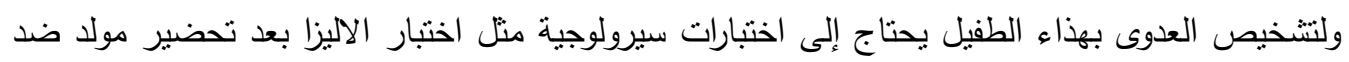
متخصص (Antigen) . لذلك نم فحص عدد 200 عينة سيرم منهم 120اغنام (60 صغيرة و 60 بالغة ) و 80 ماعز (40 صغيرة و40 بالغة) وتم اخذ عينه براز من كل حيوان لفحصها للطفيليات الداخلية في بئي أماكن مختلفة بمحافظة الثرقية. تبين من تلك الدراسة أن نسبه الإصابة بالساركوسست 47.50 \% (57 ) في الأغنام و 40 \% (32) فالأنة

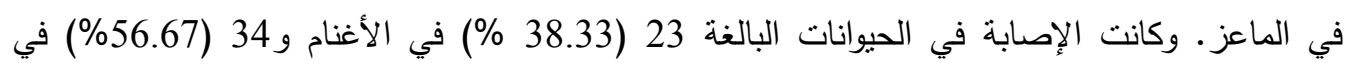

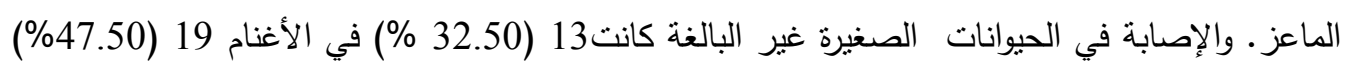

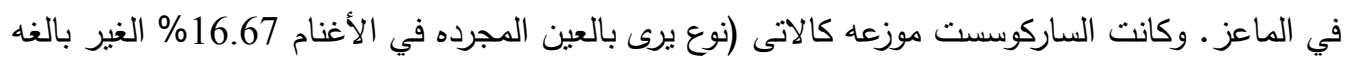

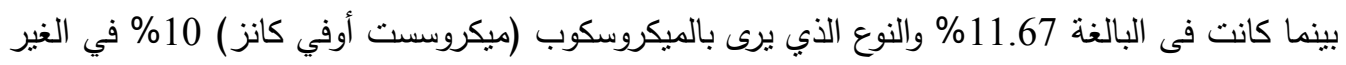

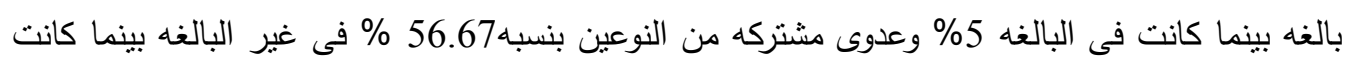

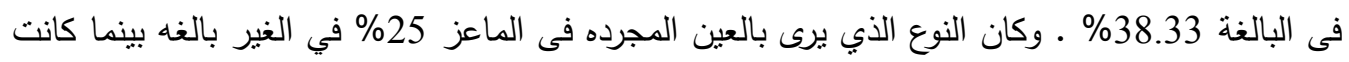

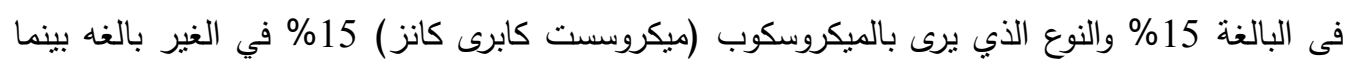

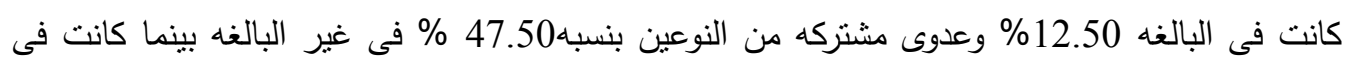
البالغه 32.50\%

أثتتت هذه الدراسة أن الإصابة بطفيل الساركوسيست أحدثت نقص معنوي في العدد الكلى لكرات

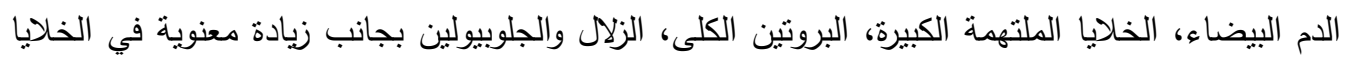

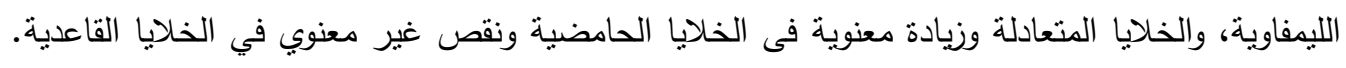

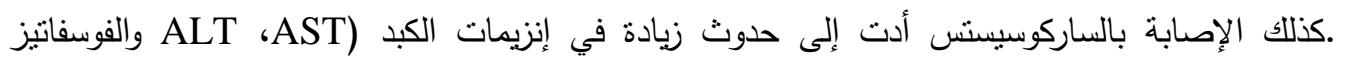
القاعدى). 
من ثلاك الدراسة نستخلص أن طفيل الساركوسيستس يصيب الماعز والأغنام سواء كانت تلك

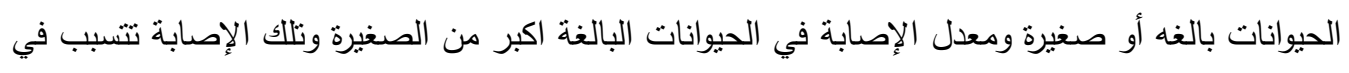
بعض التغيرات في الوظائف البيوكيميائيه في الحيوانات. 